\title{
Efektivitas Pelapisan Rizobakteri pada Benih Cabai setelah Disimpan dalam Meningkatkan Pertumbuhan Tanaman serta Mengendalikan Penyakit Busuk Phytophthora
}

\section{The Effectiveness of Seed Treatment Using Rhizobacteria on Hot Pepper Seeds after Storage, on Improving Plant Growth and Controlling Phytophthora Blight Disease}

\author{
Ainun Nur Maulidina Hikmawati ${ }^{1}$, Satriyas Ilyas ${ }^{1 *}$ dan Dyah Manohara ${ }^{2}$ \\ ${ }^{1}$ Departemen Agronomi dan Hortikultura, Fakultas Pertanian, Institut Pertanian Bogor \\ (Bogor Agricultural University), Jl. Meranti, Kampus IPB Darmaga, Bogor 16680, Indonesia \\ Telp.\& Faks.62-251-8629353 e-mail agrohort@apps.ipb.ac.id \\ ${ }^{2}$ Balai Penelitian Tanaman Rempah dan Obat (Balittro), Kementerian Pertanian, Jalan Tentara Pelajar \\ No.3, Bogor 16680, Indonesia \\ *Penulis Korespondensi : satriyas252@gmail.com
}

Disetujui : 4 Oktober 2018/ Published Online2 Januari 2019

\begin{abstract}
Mostly farmers use synthetic fungicides to control phytophthora blight disease that are harmful to the environment and health. The objectives of this experiment were to evaluate the effectiveness of seed treatment using rhizobacteria isolates on hot pepper seeds after 7 months of storage, on improving plant growth, yield, and controlling the phytophthora blight disease. The experiment was conducted from January to June 2017 at Laboratory of Disease, Balittro, and Green House of Leuwikopo Experimental Field, Department of Agronomy and Horticulture, IPB. The experiment was arranged in a randomized block design with single factor (seed treatment) and four replications. The 12 seed treatments consisted of positive control, negative control, seed coating with Na alginat $2.5 \%$ plus E1+F2B1 or ST116B or CM8 isolates, biopriming 24 hours plus E1 $+F 2 B 1$ or ST116B or CM8, biopriming 48 hours plus E1+F2B1 or ST116B or CM8, and metalaxyl 800 ppm. Inoculated soil (5 $g$ per plant) was applied around the root when the plant was 5 weeks after transplanting. The results showed that biopriming plus ST116B for 24 hours applied on hot pepper seeds before storage and the seeds were planted after being stored for 7 months at ambient room $\left(27-30^{\circ} \mathrm{C}\right)$ improved plant growth eventhough the soilwas inoculated by $P$. capsisi. Biopriming plus ST116B for 24 hours and seed coating plus ST116B decreased phytophthora blight disease from 93.8\% (positive control) to $65.6 \%$. Metalaxyl seed treatment was not effective in increasing plant growth and controlling phytophthora blight disease.
\end{abstract}

Keywords: biopriming, metalaxyl, Phytophthora capsici, seed coating

\begin{abstract}
ABSTRAK
Pengendalian penyakit busuk phytophthora pada cabai umumnya menggunakan fungisida sintetisyang berbahaya bagi lingkungan dan kesehatan. Penelitian ini bertujuan mengevaluasi efektivitas pelapisan rizobakteri pada benih cabai setelah disimpan selama 7 bulan, terhadap pertumbuhan tanaman dan hasil, serta ketahanan tanaman cabai terhadap penyakit busuk phytophthora. Penelitian ini dilaksanakan pada bulan Januari hingga Juni 2017 di Laboratorium Penyakit Balai Penelitian Tanaman Rempah dan Obat (Balittro) dan Rumah Kaca Kebun Percobaan Leuwikopo, Departemen Agronomi dan Hortikultura, IPB. Rancangan penelitian yang digunakan adalah RKLT satu faktor (perlakuan benih) dengan empat ulangan. Percobaan terdiri atas dua belas perlakuan yaitu kontrol positif, kontrol negatif, seed coating Na alginat $2.5 \%$ plus E1+F2B1 atau ST116B atau CM8, biopriming 24 jam plus E1+F2B1 atau ST116B atau CM8, biopriming 48 jam plus F2B1 atau ST116B atau CM8, dan priming metalaksil 800 ppm. Tanah inokulum sebanyak 5 gram per tanaman disebar di sekitar perakaran ketika tanaman berumur 5 minggu setelah pindah-tanam. Hasil penelitian menunjukkan bahwa perlakuan biopriming 24 jam plus ST116B sebelum disimpan kemudian benih ditanam setelah disimpan 7 bulan pada suhu kamar $\left(27-30^{\circ} \mathrm{C}\right)$ nyata meningkatkan pertumbuhan tanaman meskipun tanah telah diinokulasi P. capsici. Perlakuan biopriming 24 jam plus ST116B dan seed coating plus ST116B mampu menurunkan kejadian penyakit busuk phytophthora dari $93.8 \%$ (kontrol positif) menjadi $65.6 \%$. Perlakuan benih menggunakan metalaksil tidak efektif dalam meningkatkan pertumbuhan dan ketahanan tanaman terhadap penyakit busuk phytophthora.
\end{abstract}

Katakunci: biopriming, metalaksil, Phytophthora capsici, seed coating 


\section{PENDAHULUAN}

Cabai merupakan tanaman komoditas hortikultura yang banyak dibudidayakan petani karena memiliki nilai ekonomi yang tinggi. Hingga saat ini, produksi cabai merah Indonesia masih di bawah potensi hasilnya yang dapat mencapai 12-20 ton. Produktivitas cabai merah pada tahun 2015 mencapai 8.65 ton $\mathrm{ha}^{-1}$ (Kementan, 2016). Menurut Ramdan (2014), kendala utama budidaya cabai adalah adanya serangan organisme pengganggu tanaman (OPT). Ketika curah hujan meningkat, pembusukan pada tanaman akan meningkat sehingga menurunkan hasil produksi. Salah satu penyakit pada tanaman cabai adalah busuk phytophthora yang disebabkan cendawan Phytophthora capsici L.

Benih unggul bermutu merupakan kunci utama keberhasilan suatu usaha tani. Peningkatan mutu benih dapat dilakukan dengan perlakuan benih (seed treatment) (Ilyas, 2012). Perlakuan benih yang sering dilakukan petani adalah dengan menggunakan fungisida sintetis yang berbahaya bagi lingkungan dan kesehatan, serta memungkinkan adanya resistensi hama dan penyakit tumbuhan. Strategi yang dapat digunakan untuk meningkatkan pertumbuhan tanaman cabai adalah dengan menggunakan PGPR (Plant Growth Promoting Rhizobacteria). Berdasarkan penelitian Sutariati et al. (2006), perlakuan benih dengan rizobakteri secara nyata meningkatkan viabilitas benih cabai yang diuji. Rizobakteri berfungsi sebagai pemacu pertumbuhan tanaman pada fase vegetatif dan generatif (Taufik, 2010). Selain itu pada penelitian Ibrahim et al. (2014), rizobakteri juga berpotensi sebagai agen pengendali penyakit busuk pangkal batang pada tanaman cabai.

Madyasari (2017) melakukan penelitian untuk menguji mutu benih cabai yang dilapisi rizobakteri kemudian disimpan selama 6 bulan. Hasil penelitian menunjukkan, perlakuan rizobakteri dapat meningkatkan pertumbuhan tanaman pada saat persemaian dan setelah pindah tanam. Namun tanaman yang diberi inokulum $P$. capsici mengalami kematian sebelum masa generatif selesai, sehingga tidak dapat dilakukan pengamatan terhadap hasil panen. Hal ini disebabkan inokulum $P$. capsici yang diberikan terlalu banyak, yaitu $10 \mathrm{~g}$. Berdasarkan penelitian tersebut perlu dilakukan penelitian lanjutan dengan mengevaluasi mutu benih cabai yang diberi perlakuan rizobakteri dan telah disimpan selama 7 bulan, kemudian ditanam di rumah kaca. Evaluasi perlakuan benih dilakukan terhadap pertumbuhan tanaman dan hasil cabai, serta ketahanannya terhadap serangan penyakit busuk phytophthora dengan tanah inokulum P.capsici yang lebih rendah, yaitu 5 g. Penelitian ini bertujuan untuk mengevaluasi efektivitas perlakuan pelapisan rizobakteri pada benih cabai yang telah disimpan selama 7 bulan, terhadap pertumbuhan tanaman dan hasil cabai, serta ketahanan tanaman cabai terhadap penyakit busuk phytophthora.

\section{BAHAN DAN METODE}

Penelitian ini dilaksanakan di Laboratorium Penyakit, Balai Penelitian Tanaman Rempah dan Obat (Balittro), dan Rumah Kaca Leuwikopo Departemen Agronomi dan Hortikultura, Fakultas Pertanian, Institut Pertanian Bogor pada bulan Januari hingga Juni 2017. Penelitian dilakukan dengan menggunakan Rancangan Kelompok Lengkap Teracak satu faktor (perlakuan benih) yang terdiri atas dua belas perlakuan, dan empat ulangan. Masing-masing ulangan dilakukan penanaman sebanyak delapan bibit cabai, sehingga seluruh tanaman berjumlah 384 tanaman (setelah pindah tanam). Perlakuan yang berpengaruh nyata diuji lanjut dengan Duncan Multiple Range Test (DMRT).

Perlakuan benih pada percobaan ini sebagai berikut:

1. Kontrol negatif

2. Kontrol positif

3. Seed coating $\mathrm{Na}$ alginat $2.5 \%$ plus isolat $\mathrm{E} 1+\mathrm{F} 2 \mathrm{~B} 1$

4. Seed coating $\mathrm{Na}$ alginat $2.5 \%$ plus isolat ST116B

5. Seed coating Na alginat $2.5 \%$ plus isolat $\mathrm{CM} 8$

6. Biopriming plus $\mathrm{E} 1+\mathrm{F} 2 \mathrm{~B} 1$ (24 jam)

7. Biopriming plus ST116B (24 jam)

8. Biopriming plus CM8 (24 jam)

9. Biopriming plus $\mathrm{E} 1+\mathrm{F} 2 \mathrm{~B} 1$ (48 jam)

10. Biopriming plus ST116B (48 jam)

11. Biopriming plus CM8 (48 jam)

12. Priming dengan metalaksil $800 \mathrm{ppm}$

Benih cabai varietas Laris (produksi PT. East West Seed Indonesia) yang digunakan telah diberi perlakuan pelapisan rizobakteri serta penyimpanan pada kondisi ruang (suhu $27-30{ }^{\circ} \mathrm{C}$ ) selama 7 bulan dalam plastik polypropilen 0.8 $\mathrm{mm}$. Daya berkecambah benih sebelum disimpan adalah $88 \%$, dan kerapatan populasi rizobakterinya $10^{7}-10^{8} c f u \quad \mathrm{~mL}^{-1}$. Kerapatan populasi rizobakteri saat 6 bulan setelah simpan adalah $0-10^{2}$ pada permukaan benih dan $10^{4}$ dalam jaringan benih (Madyasari, 2017; Madyasari et al., 2017). Benih yang telah disimpan kemudian ditanam di dalam rumah kaca. Benih disemai dalam tray semai yang berisi campuran tanah, pupuk kandang, dan arang sekam $(1 / 1 / 1 \mathrm{v} / \mathrm{v} / \mathrm{v})$. Setiap ulangan terdiri atas 25 benih, sehingga 
terdapat 1200 satuan pengamatan. Variabel pengamatan pada fase pembibitan meliputi daya berkecambah, indeks vigor, keserempakan tumbuh, tinggi bibit, dan jumlah daun. Tanaman dipelihara di persemaian (dalam rumah kaca) hingga berumur 35 hari setelah tanam (HST).

Sebanyak delapan bibit tiap perlakuan (dipilih secara acak) dipindahkan ke polybag (satu bibit per polybag) berukuran $35 \mathrm{~cm} \times 35 \mathrm{~cm}$. Khusus untuk perlakuan kontrol dipindahkan delapan bibit sebagai kontrol negatif (tanpa perlakuan rizobakteri dan tanah tidak diiokulasi $P$. capsici) dan delapan bibit sebagai kontrol positif (tanpa perlakuan rizobakteri tetapi tanah diinokulasi $P$. capsici). Media tanam yang digunakan berupa tanah, pupuk kandang, dan arang sekam $(2: 1: 1 \mathrm{v} / \mathrm{v} / \mathrm{v})$. Media yang telah berisi bibit diletakkan secara teratur dengan jarak $30 \mathrm{~cm}$ x $50 \mathrm{~cm}$. Penyiraman dilakukan setiap hari pada waktu pagi atau sore hari. Pemupukan dilakukan pada tanaman yang berumur 2, 4, 5, dan 6 minggu setelah pindah-tanam (MSP) menggunakan pupuk NPK Mutiara (15:15:15) sebanyak $50 \mathrm{ml}$ per tanaman dengan konsentrasi $2 \mathrm{~g} \mathrm{~L}^{-1}$. Dilakukan pengajiran pada $2 \mathrm{MSP}$, pengendalian hama (menggunakan insektisida) dan gulma jika diperlukan, dan pewiwilan tunas air secara kontinyu.

Penambahan tanah inokulum dilakukan pada saat tanaman berumur 5 MSP. Tanah inokulum dibuat dengan cara mencampurkan tanah dan pasir kering (2:1) dengan $4 \%$ oat meal (halus) dan diberi air hingga mencapai kelembaban berkisar antara 60-80\% kapasitas lapang. Campuran media tersebut dimasukkan ke dalam plastik tahan panas, kemudian disterilisasi dengan autoclave pada suhu $120{ }^{\circ} \mathrm{C}$ selama 30 menit. Setiap plastik berisi media sebanyak 50 gram. Sebanyak lima potongan biakan/ plastik (menggunakan cork borer) diinvestasikan ke campuran media yang sudah steril kemudian diinkubasi pada suhu ruang $\left(23-25{ }^{\circ} \mathrm{C}\right)$ selama 2 minggu. Selama periode inkubasi dilakukan pembalikan plastik berisi tanah inokulum setiap 3 hari sekali. Tanah inokulum yang telah diinkubasi diaduk merata sebelum diaplikasikan ke tanah. Cara pembuatan tanah inokulum ini mengacu pada metode Manohara (1988). Investasi tanah inokulum dilakukan dengan cara menyebar $5 \mathrm{~g}$ tanah inokulum di sekeliling tanaman dan pangkal batang tidak dilukai.

Variabel pengamatan setelah pindah tanam meliputi tinggi tanaman, jumlah daun, dan kejadian penyakit. Data yang diperoleh dianilisis untuk mengetahui pengaruh dari perlakuan dengan melakukan uji $\mathrm{F}$ pada taraf nyata $\alpha=5 \%$. Apabila terdapat pengaruh nyata, maka dilakukan uji lanjut dengan metode Duncan Multiple Range Test (DMRT) pada taraf $\alpha=5 \%$ (Gomez dan Gomez, 1995).

\section{HASIL DAN PEMBAHASAN}

\section{Kondisi Umum Percobaan}

Penelitian dilakukan di rumah kaca kebun percobaan Leuwikopo, Kecamatan Dramaga, Kabupaten Bogor dengan ketinggian $240 \mathrm{~m}$ dpl dengan suhu rata-rata $27-35{ }^{\circ} \mathrm{C}$. Rumah kaca memiliki jendela kawat yang berlubang, sehingga air hujan dapat masuk ketika hujan disertai angin. Atap rumah kaca mengalami kebocoran pada beberapa bagian diakibatkan hujan deras. Sebelum digunakan penelitian, rumah kaca sudahdigunakan untuk penelitian cabai, kemudian dibiarkan selama satu tahun dan digunakan sebagai tempat penyimpanan brangkasan kedelai. Terdapat pertanaman jarak pagar (Jatropa curcas) dan ubi jalar (Ipomoea batatas) di sekitar rumah kaca. Hama yang menyerang pada tanaman cabai adalah ulat jengkal (Chrysodeixis chalcites) dan tungau (Polyphagotarsonemus latus). Tungau mengakibatkan beberapa tanaman menjadi kerdil bahkan mati. Pengendalian terhadap ulat jengkal dilakukan secara manual yaitu dengan pengambilan ulat, sedangkan pengendalian terhadap tungau dilakukan dengan penyemprotan insektisida berbahan aktif karbosulfan $1.1 \%$ dan piridaben $13.5 \%$ secara bergantian.

\section{Peningkatan Pertumbuhan Tanaman Cabai yang Dilapisi Rizobakteri}

Pengaruh perlakuan benih terhadap vigor dan viabilitas benih di persemaian dapat dilihat pada Tabel 1. Perlakuan seed coating plus

Tabel 1. Pengaruh perlakuan benih terhadap keserempakan tumbuh dan daya berkecambah setelah disimpan 7 bulan

\begin{tabular}{lcl}
\hline Perlakuan Benih & $\mathrm{K}_{\mathrm{ST}}(\%)$ & $\mathrm{DB}(\%)$ \\
\hline Kontrol & $46.7 \mathrm{bcd}$ & $64.2 \mathrm{~cd}$ \\
Seed coating plus E1+F2B1 & $45.8 \mathrm{~cd}$ & $72.3 \mathrm{abc}$ \\
Seed coating plust ST116B & $38.3 \mathrm{~cd}$ & $81.7 \mathrm{a}$ \\
Seed coating plus CM8 & $68.3 \mathrm{a}$ & $80.0 \mathrm{ab}$ \\
Biopriming E1+F2B1 (24jam) & $35.0 \mathrm{~d}$ & $60.0 \mathrm{de}$ \\
Biopriming ST116B (24 jam) & $32.5 \mathrm{~d}$ & $65.0 \mathrm{~cd}$ \\
Biopriming CM8 (24 jam) & $62.5 \mathrm{ab}$ & $73.3 \mathrm{abc}$ \\
Biopriming E1+F2B1 (48jam) & $53.3 \mathrm{abc}$ & $69.2 \mathrm{bcd}$ \\
Biopriming ST116B (48 jam & $36.7 \mathrm{~d}$ & $52.5 \mathrm{e}$ \\
Biopriming CM8 (48 jam) & $33.3 \mathrm{~d}$ & $71.7 \mathrm{abc}$ \\
Priming dengan metalaksil & $4.2 \mathrm{e}$ & $35.0 \mathrm{f}$ \\
KK & 27.289 & 12.006 \\
\hline
\end{tabular}

Keterangan: Angka yang diikuti huruf berbeda pada kolom yang sama berbeda nyata berdasarkan DMRT pada taraf $\alpha=5 \%$, $\mathrm{K}_{\mathrm{ST}}$ : keserempakan tumbuh, DB: daya berkecambah. 
ST116B dan seed coating plus CM8 memiliki daya berkecambah nyata lebih tinggi dibandingkan kontrol. Perlakuan seed coating plus CM8 juga memiliki nilai keserempakan tumbuh tertinggi. Benih dengan perlakuan metalaksil memiliki daya berkecambah dan keserempakan tumbuh yang sangat rendah dibandingkan semua perlakuan. Hal ini disebabkan fungisida metalaksil bersifat toksik jika digunakan dalam waktu lama, sehingga dapat menurunkan vigor dan viabilitas benih. Menurut Madyasari (2017), benih dengan perlakuan metalaksil yang disimpan selama 24 minggu mengalami kematian atau tumbuh abnormal.

Perlakuan P3 (seed coating plus CM8) memiliki nilai yang relatif tinggi pada variabel tinggi bibit, meskipun tidak berbeda nyata dengan kontrol (Tabel 2). Hasil penelitian Madyasari (2017), perlakuan pelapisan dengan rizobakteri dan metalaksil tidak menunjukkan hasil yang nyata terhadap tinggi bibit. Jumlah rizobakteri pada benih diduga mengalami penurunan pada saat persemaian. Perlakuan P9 (biopriming plus CM8 selama 48 jam) memiliki nilai tertinggi pada variabel jumlah daun meskipun tidak berbeda dengan kontrol pada 3 minggu setelah tanam (MST). Hal ini sesuai dengan penelitian Rosadiah et al. (2015), perlakuan biopriming plus CM8 selama 24 jam nyata meningkatkan tinggi tanaman dan jumlahdaun. Menurut Ibrahim et al. (2014), diduga rizobakteri mampu menyediakan dan memobilisasi unsur hara sehingga terjadi peningkatkan jumlah daun. Selain itu, rizobakteri diduga dapat menghasilkan hormon pertumbuhan, salah satunya adalah IAA (indole asetic acid).

Perlakuan rizobakteri pada minggu ke 1-6 MSP tidak berpengaruh nyata terhadap tinggi tanaman (Tabel 3). Perlakuan biopriming plus mengontrol stres abiotik, dan mengendalikan penyakit. Perlakuan metalaksil menunjukkan hasil yang nyata lebih rendahdibandingkan kontrol positif (kontrol dengan P. capsici) pada variabel tinggi tanaman. Hal ini diduga disebabkan karena metalaksil tidak dapat menghasilkan senyawa yang memacu pertumbuhan seperti rizobakteri yang berfungsi sebagai PGPR.

Pengaruh perlakuan benih terhadap jumlah daun setelah pindah tanam dapat dilihat pada Tabel 4. Perlakuan benih tidak berpengaruh nyata terhadap variabel jumlah daun pada awal pertumbuhan. Setelah dilakukan inokulasi $P$. capsici terlihat adanya perbedaan. Pelakuan biopriming plus ST116B selama 24 jam menunjukkan nilai nyata lebih tinggi jika dibandingkan dengan kontrol positif. Hal ini menunjukkan bahwa perlakuan biopriming plus ST116B selama 24 jam dapat mempertahankan pertumbuhan tanaman meskipun telah diinokulasi dengan $P$. capsici. Menurut Ibrahim et al. (2014), perlakuan benih dengan isolat ST116B menghasilkan jumlah daun yang nyata lebih tinggi dibandingkan semua perlakuan lainnya. Tinggi tanaman tidak menunjukkan nilai yang berbeda nyata antara semua perlakuan, namun pada 2 MSP perlakuan ST116B menunjukkan nilai yang lebih tinggi dibandingkan semua perlakuan.

Tabel 2. Pengaruh perlakuan benih setelah disimpan 7 bulan terhadap tinggi bibit dan jumlah daun pada 1-3 minggu setelah tanam di persemaian

\begin{tabular}{lcccccc}
\hline Perlakuan & \multicolumn{3}{c}{ Tinggi Bibit } & \multicolumn{3}{c}{ Jumlah Daun } \\
\cline { 2 - 7 } Benih & $1 \mathrm{MST}$ & $2 \mathrm{MST}$ & $3 \mathrm{MST}$ & $1 \mathrm{MST}$ & $2 \mathrm{MST}$ & $3 \mathrm{MST}$ \\
\hline P0 & $3.43 \mathrm{ab}$ & $4.35 \mathrm{a}$ & $5.48 \mathrm{a}$ & $2.8 \mathrm{ab}$ & $3.3 \mathrm{ab}$ & $4.1 \mathrm{ab}$ \\
P1 & $3.12 \mathrm{ab}$ & $3.88 \mathrm{abc}$ & $4.20 \mathrm{bc}$ & $2.8 \mathrm{ab}$ & $3.3 \mathrm{ab}$ & $3.6 \mathrm{bc}$ \\
P2 & $3.03 \mathrm{~b}$ & $3.37 \mathrm{~cd}$ & $4.00 \mathrm{c}$ & $3.0 \mathrm{a}$ & $3.0 \mathrm{~b}$ & $3.8 \mathrm{abc}$ \\
P3 & $3.70 \mathrm{a}$ & $4.22 \mathrm{ab}$ & $5.53 \mathrm{a}$ & $3.0 \mathrm{a}$ & $3.8 \mathrm{a}$ & $4.0 \mathrm{ab}$ \\
P4 & $3.07 \mathrm{~b}$ & $3.54 \mathrm{bc}$ & $4.01 \mathrm{bc}$ & $2.8 \mathrm{ab}$ & $3.3 \mathrm{ab}$ & $3.6 \mathrm{bc}$ \\
P5 & $2.37 \mathrm{c}$ & $2.78 \mathrm{~d}$ & $3.62 \mathrm{c}$ & $2.5 \mathrm{ab}$ & $2.8 \mathrm{~b}$ & $3.7 \mathrm{bc}$ \\
P6 & $2.88 \mathrm{bc}$ & $3.19 \mathrm{~cd}$ & $3.55 \mathrm{c}$ & $3.0 \mathrm{a}$ & $3.0 \mathrm{~b}$ & $3.4 \mathrm{bc}$ \\
P7 & $3.08 \mathrm{~b}$ & $3.17 \mathrm{~cd}$ & $3.60 \mathrm{c}$ & $3.0 \mathrm{a}$ & $3.0 \mathrm{~b}$ & $3.2 \mathrm{c}$ \\
P8 & $2.33 \mathrm{c}$ & $2.76 \mathrm{~d}$ & $3.24 \mathrm{c}$ & $2.3 \mathrm{~b}$ & $2.8 \mathrm{~b}$ & $3.0 \mathrm{c}$ \\
P9 & $2.89 \mathrm{bc}$ & $3.53 \mathrm{bc}$ & $5.22 \mathrm{ab}$ & $3.0 \mathrm{a}$ & $3.8 \mathrm{a}$ & $4.5 \mathrm{a}$ \\
P10 & $1.19 \mathrm{~d}$ & $1.41 \mathrm{e}$ & $1.66 \mathrm{~d}$ & $1.3 \mathrm{c}$ & $1.8 \mathrm{c}$ & $1.9 \mathrm{~d}$ \\
\hline KK & 15.110 & 15.572 & 20.943 & 14.565 & 16.066 & 15.022 \\
\hline Ke
\end{tabular}

Keterangan: Angka yang diikuti huruf berbeda pada kolom yang sama berbeda nyata berdasarkan DMRT pada taraf $\alpha=$ 5\%. P0 (kontrol), P1 (Seed coating plus E1+F2B1), P2 (Seed coating plus ST116B), P3 (Seed coating plus CM8), P4 (Biopriming plus E1+F2B1 (24 jam)), P5 (Biopriming plus ST116B (24 jam)), P6 (Biopriming plus CM8 (24 jam)), P7 (Biopriming plus E1+F2B1 (48 jam)), P8 (Biopriming plus ST116B (48 jam)), P9 (Biopriming plus CM8 (48 jam)), P10 (Priming dengan metalaksil). MST: minggu setelah tanam. 
Tabel 3. Pengaruh perlakuan benih setelah disimpan 7 bulan terhadap tinggi tanaman 1-7 minggu setelah pindah tanam di polybag

\begin{tabular}{llllllll}
\hline Perlakuan & \multicolumn{7}{c}{ Tinggi Tanaman $(\mathrm{cm})$} \\
\cline { 2 - 7 } Benih & $1 \mathrm{MSP}$ & $2 \mathrm{MSP}$ & $3 \mathrm{MSP}$ & $4 \mathrm{MSP}$ & $5 \mathrm{MSP}$ & $6 \mathrm{MSP}$ & $7 \mathrm{MSP}$ \\
\hline P01 & $7.22 \mathrm{ab}$ & $9.21 \mathrm{~b}$ & $12.50 \mathrm{abc}$ & $16.80 \mathrm{ab}$ & $29.57 \mathrm{a}$ & $32.69 \mathrm{ab}$ & $49.71 \mathrm{a}$ \\
P02 & $8.06 \mathrm{a}$ & $10.34 \mathrm{a}$ & $12.91 \mathrm{ab}$ & $17.30 \mathrm{ab}$ & $25.30 \mathrm{ab}$ & $31.14 \mathrm{ab}$ & $32.52 \mathrm{~cd}$ \\
P1 & $6.52 \mathrm{bc}$ & $8.64 \mathrm{bc}$ & $12.32 \mathrm{abc}$ & $16.91 \mathrm{ab}$ & $24.30 \mathrm{~b}$ & $30.54 \mathrm{ab}$ & $34.55 \mathrm{~cd}$ \\
P2 & $5.57 \mathrm{def}$ & $8.15 \mathrm{~cd}$ & $13.38 \mathrm{a}$ & $18.40 \mathrm{a}$ & $25.43 \mathrm{ab}$ & $31.70 \mathrm{ab}$ & $37.81 \mathrm{bc}$ \\
P3 & $6.63 \mathrm{bc}$ & $8.89 \mathrm{bc}$ & $12.66 \mathrm{abc}$ & $17.82 \mathrm{ab}$ & $25.66 \mathrm{ab}$ & $29.61 \mathrm{ab}$ & $32.69 \mathrm{~cd}$ \\
P4 & $6.14 \mathrm{cde}$ & $8.35 \mathrm{bcd}$ & $12.14 \mathrm{abc}$ & $16.92 \mathrm{ab}$ & $25.60 \mathrm{ab}$ & $31.01 \mathrm{ab}$ & $35.65 \mathrm{bcd}$ \\
P5 & $6.39 \mathrm{bcd}$ & $8.92 \mathrm{bc}$ & $13.10 \mathrm{a}$ & $18.35 \mathrm{a}$ & $27.34 \mathrm{ab}$ & $35.10 \mathrm{a}$ & $42.95 \mathrm{ab}$ \\
P6 & $5.12 \mathrm{fg}$ & $7.44 \mathrm{~d}$ & $11.35 \mathrm{bc}$ & $16.57 \mathrm{ab}$ & $25.49 \mathrm{ab}$ & $31.24 \mathrm{ab}$ & $34.83 \mathrm{~cd}$ \\
P7 & $5.45 \mathrm{efg}$ & $7.42 \mathrm{~d}$ & $10.96 \mathrm{c}$ & $15.46 \mathrm{~b}$ & $23.51 \mathrm{bc}$ & $28.93 \mathrm{~b}$ & $31.29 \mathrm{~cd}$ \\
P8 & $5.94 \mathrm{cdef}$ & $8.10 \mathrm{~cd}$ & $12.11 \mathrm{abc}$ & $17.01 \mathrm{ab}$ & $26.63 \mathrm{ab}$ & $32.88 \mathrm{ab}$ & $35.34 \mathrm{~cd}$ \\
P9 & $6.79 \mathrm{bc}$ & $8.90 \mathrm{bc}$ & $12.56 \mathrm{abc}$ & $17.36 \mathrm{ab}$ & $25.92 \mathrm{ab}$ & $32.62 \mathrm{ab}$ & $35.79 \mathrm{bcd}$ \\
P10 & $4.64 \mathrm{~g}$ & $6.02 \mathrm{e}$ & $9.01 \mathrm{~d}$ & $12.58 \mathrm{c}$ & $18.79 \mathrm{c}$ & $21.81 \mathrm{c}$ & $28.48 \mathrm{~d}$ \\
\hline KK & 10.311 & 8.326 & 9.793 & 10.312 & 13.742 & 13.822 & 14.310 \\
\hline
\end{tabular}

Keterangan: Detil seperti pada Tabel 2. Tanah inokulum P. capsici diberikan pada 5 minggu setelah pindah-tanam di sekitar pangkal batang tanaman cabai di bawah permukaan tanah.

Tabel 4. Pengaruh perlakuan benih setelah disimpan 7 bulan terhadap jumlah daun 1-7 minggu setelah pindah tanam di polybag

\begin{tabular}{lcllllll}
\hline Perlakuan & \multicolumn{7}{c}{ Jumlah Daun } \\
\cline { 2 - 7 } Benih & $1 \mathrm{MSP}$ & $2 \mathrm{MSP}$ & $3 \mathrm{MSP}$ & $4 \mathrm{MSP}$ & $5 \mathrm{MSP}$ & $6 \mathrm{MSP}$ & $7 \mathrm{MSP}$ \\
\hline P01 & $7.0 \mathrm{a}$ & $9.3 \mathrm{ab}$ & $12.5 \mathrm{ab}$ & $16.5 \mathrm{ab}$ & $24.8 \mathrm{a}$ & $32.5 \mathrm{ab}$ & $67.0 \mathrm{a}$ \\
P02 & $7.0 \mathrm{a}$ & $9.8 \mathrm{a}$ & $12.5 \mathrm{ab}$ & $17.3 \mathrm{ab}$ & $25.5 \mathrm{a}$ & $28.8 \mathrm{ab}$ & $30.3 \mathrm{c}$ \\
P1 & $6.8 \mathrm{ab}$ & $9.5 \mathrm{ab}$ & $12.0 \mathrm{ab}$ & $16.0 \mathrm{~b}$ & $23.0 \mathrm{a}$ & $26.5 \mathrm{ab}$ & $33.8 \mathrm{bc}$ \\
P2 & $6.3 \mathrm{abc}$ & $9.3 \mathrm{ab}$ & $13.5 \mathrm{a}$ & $18.5 \mathrm{a}$ & $25.5 \mathrm{a}$ & $31.5 \mathrm{ab}$ & $41.8 \mathrm{bc}$ \\
P3 & $6.5 \mathrm{ab}$ & $9.3 \mathrm{ab}$ & $12.8 \mathrm{ab}$ & $16.5 \mathrm{ab}$ & $24.0 \mathrm{a}$ & $28.3 \mathrm{ab}$ & $27.8 \mathrm{c}$ \\
P4 & $6.0 \mathrm{bc}$ & $8.8 \mathrm{bc}$ & $12.3 \mathrm{ab}$ & $16.5 \mathrm{ab}$ & $24.3 \mathrm{a}$ & $28.0 \mathrm{ab}$ & $30.0 \mathrm{c}$ \\
P5 & $6.8 \mathrm{ab}$ & $9.8 \mathrm{a}$ & $13.3 \mathrm{ab}$ & $16.5 \mathrm{ab}$ & $25.8 \mathrm{a}$ & $34.5 \mathrm{a}$ & $49.8 \mathrm{ab}$ \\
P6 & $6.0 \mathrm{bc}$ & $8.3 \mathrm{bc}$ & $12.3 \mathrm{ab}$ & $16.0 \mathrm{~b}$ & $23.3 \mathrm{a}$ & $26.8 \mathrm{ab}$ & $30.5 \mathrm{c}$ \\
P7 & $5.5 \mathrm{c}$ & $8.3 \mathrm{~cd}$ & $11.8 \mathrm{~b}$ & $15.5 \mathrm{bc}$ & $22.0 \mathrm{ab}$ & $24.0 \mathrm{bc}$ & $26.3 \mathrm{c}$ \\
P8 & $6.8 \mathrm{ab}$ & $9.0 \mathrm{abc}$ & $13.5 \mathrm{a}$ & $17.5 \mathrm{ab}$ & $25.0 \mathrm{a}$ & $28.8 \mathrm{ab}$ & $37.8 \mathrm{bc}$ \\
P9 & $7.0 \mathrm{a}$ & $9.5 \mathrm{ab}$ & $12.8 \mathrm{ab}$ & $16.8 \mathrm{ab}$ & $25.0 \mathrm{a}$ & $29.3 \mathrm{ab}$ & $38.5 \mathrm{bc}$ \\
P10 & $5.5 \mathrm{c}$ & $7.5 \mathrm{~cd}$ & $10.3 \mathrm{c}$ & $13.8 \mathrm{c}$ & $18.0 \mathrm{~b}$ & $17.3 \mathrm{c}$ & $31.0 \mathrm{c}$ \\
\hline KK & 2.063 & 1.833 & 2.160 & 2.266 & 3.157 & 5.391 & 7.833 \\
\hline
\end{tabular}

Keterangan: Detil seperti pada Tabel 2 dan 3. Sebelum diolah data ditransformasi ke $(\mathrm{x}+\mathrm{x} \text { rata-rata })^{0,5}$.

\section{Ketahanan Tanaman Cabai yang Dilapisi Rizobakteri terhadap Busuk Phytophthora}

Kontrol negatif (tanpa rizobakteri, tanpa $P$. capsici) pada percobaan ini terserang penyakit busuk pangkal batang sebanyak 3.1\%. Penyebabnya adalah adanya percikan air yang mengenai tanah berpenyakit kemudian memercik pada batang tanaman sehat. Percikan air terjadi ketika hujan disertai angin yang membawa masuk air hujan ke dalam rumah kaca dan terdapat kebocoran pada atap rumah kaca bagian sudut belakang. Hal ini dibuktikan dengan tanaman kontrol yang terserang adalah tanaman yang terletak pada bagian sudut tersebut.

Persentase kejadian penyakit pada perlakuan metalaksil tidak berbeda nyata dengan kontrol positif. Hal ini menunjukkan bahwa fungisida metalaksil sudah tidak berpengaruh setelah penyimpanan selama 7 bulan. Menurut Syamsuddin (2010), meskipun metalaksil merupakan fungisida yang bersifat sistemik, namun efek pengendalian terhadap patogennya berdurasi singkat. Berbeda dengan rizobakteri yang dapat berfungsi sebagai agen biokontrol yang bersfat sistemik dalam jangka panjang, menginduksi ketahanan, dan meningkatkan pertumbuhan tanaman.

Penyimpanan yang dilakukan pada semua perlakuan benih, menunjukkan bahwa metalaksil dapat bersifat toksik jika digunakan dalam waktu yang lama, sehingga dapat menghambat pertumbuhan tanaman. Jumlah rizobakteri pada permukaan dan jaringan benih juga mengalami penurunan (Madyasari, 2017; Madyasari et al., 2017). Pengujian terhadap ketahanan tanaman cabai dilakukan pada 5 MSP dengan cara 
Tabel 5. Pengaruh perlakuan benih setelah disimpan 7 bulan terhadap kejadian penyakit busuk pangkal batang 6-14 hari setelah inokulasi

\begin{tabular}{lccccc}
\hline \multirow{2}{*}{ Perlakuan } & \multicolumn{5}{c}{ Kejadian Penyakit (\%)** } \\
\cline { 2 - 6 } & $6 \mathrm{HSI}$ & $8 \mathrm{HSI}$ & $10 \mathrm{HSI}$ & $12 \mathrm{HSI}$ & $14 \mathrm{HSI}$ \\
\hline P01 & $3.1 \mathrm{~d}$ & $3.1 \mathrm{~d}$ & $3.1 \mathrm{~d}$ & $3.1 \mathrm{c}$ & $3.1 \mathrm{c} * *$ \\
P02 & $65.6 \mathrm{ab}$ & $78.1 \mathrm{a}$ & $81.3 \mathrm{ab}$ & $90.6 \mathrm{a}$ & $93.8 \mathrm{a}$ \\
P1 & $28.1 \mathrm{c}$ & $59.4 \mathrm{abc}$ & $65.6 \mathrm{ab}$ & $71.9 \mathrm{ab}$ & $78.1 \mathrm{ab}$ \\
P2 & $40.6 \mathrm{bc}$ & $56.3 \mathrm{abc}$ & $62.5 \mathrm{abc}$ & $62.5 \mathrm{~b}$ & $65.6 \mathrm{~b}$ \\
P3 & $43.8 \mathrm{bc}$ & $75.0 \mathrm{ab}$ & $81.3 \mathrm{ab}$ & $81.3 \mathrm{ab}$ & $90.6 \mathrm{a}$ \\
P4 & $40.6 \mathrm{bc}$ & $71.9 \mathrm{ab}$ & $78.1 \mathrm{ab}$ & $81.3 \mathrm{ab}$ & $84.4 \mathrm{ab}$ \\
P5 & $28.1 \mathrm{c}$ & $37.5 \mathrm{c}$ & $40.6 \mathrm{c}$ & $59.4 \mathrm{~b}$ & $65.6 \mathrm{~b}$ \\
P6 & $46.9 \mathrm{bc}$ & $68.8 \mathrm{ab}$ & $71.9 \mathrm{ab}$ & $75.0 \mathrm{ab}$ & $78.1 \mathrm{ab}$ \\
P7 & $46.9 \mathrm{bc}$ & $68.8 \mathrm{ab}$ & $78.1 \mathrm{ab}$ & $81.3 \mathrm{ab}$ & $87.5 \mathrm{ab}$ \\
P8 & $43.8 \mathrm{bc}$ & $59.4 \mathrm{abc}$ & $75.0 \mathrm{ab}$ & $84.4 \mathrm{ab}$ & $84.4 \mathrm{ab}$ \\
P9 & $37.5 \mathrm{c}$ & $50.0 \mathrm{bc}$ & $59.4 \mathrm{bc}$ & $71.9 \mathrm{ab}$ & $84.4 \mathrm{ab}$ \\
P10 & $78.1 \mathrm{a}$ & $81.3 \mathrm{a}$ & $84.4 \mathrm{a}$ & $84.4 \mathrm{ab}$ & $90.6 \mathrm{a}$ \\
\hline KK & 11.073 & 7.906 & 6.399 & 6.4788 & 5.617 \\
\hline
\end{tabular}

Keterangan : *Nilai rata-rata dari 32 tanaman, ${ }^{* *}$ sejak 6 HSI, tanaman dipindah ke tempat yang aman dari percikan air hujan. Detil seperti pada Tabel 2 dan 3. HSI: hari setelah inokulasi, sebelum diolah data ditransformasi ke $(\mathrm{x}+\mathrm{x}$ ratarata $)^{0,5}$.

menginfestasikan tanah inokulum $P$. capsici di sekitar perakaran. Hasilnya pada 14 hari setelah inokulasi (HSI), tanaman dengan perlakuan seed coating plus ST116B dan biopriming plus ST116B selama 24 jam menunjukkan kejadian penyakit lebih rendah dibandingkan dengan perlakuan fungisida metalaksil (Tabel 5). Hal ini menunjukkan bahwa pelapisan benih dengan rizobakteri dengan cara coating maupun biopriming lebih efektif dalam mengendalikan penyakit busuk phytophthora dibandingkan dengan menggunakan fungisida sintetis. Penelitian sebelumnya (Zakia et al., 2017), juga menunjukkan bahwa perlakuan priming menggunakan metalaksil tidak efektif mengendalikan busuk phytophthora.

Hasil pengamatan terhadap kejadian penyakit busuk phytophthora menunjukkan bahwa pada 6 HSI semua perlakuan rizobakteri memiliki persentase kejadian penyakit yang lebih rendah dibandingkan kontrol positif meskipun tidak berbeda nyata kecuali P1, P5 dan P9 yang nyata lebih rendah (Tabel 5). Perlakuan seed coating plus ST116B dan biopriming plus ST116B selama 24 jam mampu menurunkan persentase kejadian penyakit (65.6\%) dibandingkan kontrol positif (93.8\%) sebesar $28.3 \%$ pada 14 HSI. Kemampuan rizobakteri dalam mengendalikan penyakit busuk phytophthora disebabkan oleh senyawa dari rizobakteri yang bersifat toksik terhadap patogen. Menurut Ibrahim et al. (2014), rizobakteri ST116B secara in vitro dapat menghambat pertumbuhan koloni $P$. capsici sebesar $50 \%$, dan memiliki zona bening yang relatif konstan. Hasil pengamatan secara mikroskopik menunjukkan bahwa rizobakteri ST116B ternyata dapat mendegradasi dinding sel $P$. capsici. Degradasi dinding sel diduga karena rizobakteri dapat mensekresi enzim ekstraseluler.

Strain $P$. capsici yang diinokulasi dari sentra produksi cabai di Jawa Timur ini memiliki tingkat virulensi yang tinggi. Gejala penyakit mulai tampak 2-3 HSI, namun tidak disajikan pada Tabel 5 karenatidak berbeda nyata. Gejala terlihat lebih cepat dibandingkan penelitian sebelumnya bahwa gejala busuk pytophthora mulai terlihat 4-5 HSI (Madyasari, 2017; Zakia et al., 2017). Tanaman yang terserang pertama kali pada 2 HSI (setara dengan 37 hari setelah pindah tanam) adalah tanaman dengan perlakuan metalaksil dengan tinggi $4.5 \mathrm{~cm}$, sedangkan tanaman dengan perlakuan lain memiliki tinggi rata-rata $25.9 \mathrm{~cm}$. Hal ini menunjukkan bahwa perlakuan metalaksil menghambat pertumbuhan tanaman dan tidak mampu menurunkan persentase kejadian penyakit. Gejala yang tampak diawali dengan batang yang berwarna coklat dan mengering kemudian daun menjadi layu. Terdapat satu tanaman dari perlakuan seed coating plus ST116B dan beberapa tanaman kontrol positif menunjukkan gejala pada 3 HSI. Gejala yang muncul lebih cepat kemungkinan disebabkan oleh kemunduran benih (daya berkecambah 64-65\% setelah disimpan 7 bulan) dan penurunan populasi rizobakteri pada saat penyimpanan dan setelah berada pada rizosfer. Berdasarkan penelitian Madyasari et al. (2017), populasi rizobakteri mengalami penurunan sejalan dengan periode simpan. Kemampuan rizobakteri mempertahankan populasinya dipengaruhi oleh kemampuan bertahan hidup, kondisi penyimpanan dan ketersediaan nutrisi di dalam jaringan 
benih.Pengamatan terhadap hasil panen tidak dapat dilakukan karena pada 16 HSI tanaman telah mengalami kematian lebih dari $75 \%$ akibat serangan penyakit busuk phytophthora. Tanaman telah memasuki fase generatif yaitu ditandai dengan munculnya bunga, namun hanya beberapa tanaman yang dapat bertahan hingga berbuah. Kerontokan bunga terjadi pada semua perlakuan. Hal ini diduga karena suhu dalam rumah kaca yang terlalu tinggi. Suhu dalam rumah kaca pada siang hari berkisar $27-35^{\circ} \mathrm{C}$. Menurut Airaki et al. (2012), suhu optimum bagi pertumbuhan tanaman cabai berkisar $25-30{ }^{\circ} \mathrm{C}$.

\section{KESIMPULAN}

Pada saat persemaian, perlakuan seed coating dengan $\mathrm{Na}$ alginat plus isolat rizobakteri CM8 meningkatkan tinggi tanaman, sedangkan perlakuan biopriming plus CM8 selama 48 jam meningkatkan tinggi tanaman dan jumlah daun. Biopriming plus ST116B selama 24 jam meningkatkan pertumbuhan tanaman meskipun tanah telah diinokulasi $P$. capsici. Perlakuan biopriming plus ST116B selama 24 jam dan seed coating plus ST116B mampu menurunkan persentase kejadian penyakit (65.6\%) dibandingkan kontrol positif $(93.8 \%)$ sebesar $28.3 \%$ meskipun benih telah disimpan selama 7 bulan pada suhu ruang $\left(27-30{ }^{0} \mathrm{C}\right)$. Perlakuan biopriming lebih efektif dibandingkan dengan perlakuan benih menggunakan metalaksil dalam meningkatkan pertumbuhan dan ketahanan tanaman terhadap busuk phytophthora. Hasil panen buah cabai tidak dapat diketahui karena $75 \%$ tanaman telah mengalami kematian sebelum masa panen.

\section{DAFTAR PUSTAKA}

Airaki, M., M. Leterrier, R.M. Mateos, R. Valderrama, M. Chaki, J.B. Barroso, L.A. Del Rio, J.M. Palma, F.J. Corpas. 2012. Metabolism of reactive oxygen species and reactive nitrogen species in pepper (Capsicum annuum L.) plants under low temperature stress. Plant, Cell and Environment. 35:281-295.

Gomez, K.A., A.A. Gomez. 1995. Prosedur Statistik untuk Penelitian Pertanian.Dalam Sjamsudin E., Baharsjah, (eds). UI Press, Jakarta.

Ibrahim, A., S. Ilyas, D. Manohara. 2014. Perlakuan benih cabai (Capsicum annuum, L) dengan Rhizobacteri untuk mengendalikan Phytophthora capsici, meningkatkan vigor benih dan pertumbuhan tanaman. Bul. Agrohorti 2(1):22-30.
Ilyas, S. 2012. Ilmu dan Teknologi Benih: Teori dan Hasil-Hasil Penelitian. IPB Press, Bogor.

[Kementan] Kementrian Pertanian. 2016. Produktivitas Cabai Besar Menurut Provinsi 2011-2015. http://www.pertanian.go.id/Da ta5tahun/pdf-HORTI2016/3.3-Produktivitas \%20Cabai\%20Besar.pdf.[11 November 2016].

Madyasari, I. 2017. Efektivitas pelapisan benih cabai dengan rizobakteri terhadap daya simpan benih, pengendalian busuk phytophthora, pertumbuhan tanaman dan produksi benih bermutu. [Tesis]. InstitutPertanian Bogor. Bogor.

Madyasari, I., C. Budiman, Syamsuddin, D. Manohara, S. Ilyas. 2017. Efektivitas seed coating dan biopriming dengan rizobakteri dalam mempertahankan viabilitas benih cabai dan rizobakteri selama penyimpanan. J. Hort. Indonesia 8(3): 192-202. Desember 2017.

Manohara, D. 1988. Ekobiologi Phytophthora palmivora (Butler) penyebab penyakit busuk pangkal batang lada (Piper nigrum L). [Disertasi]. Institut Pertanian Bogor. Bogor.

Mendes, R., P. Garbeva, J.M. Raajimakers. 2013. The rhizosphere microbiome: significance of plant beneficial, plant pathogenic, and human pathogenic microorganisms. FEMS Microbiol Rev. 37:634- 663.

Ramdan, E.P. 2014. Eksplorasi cendawan endofit sebagai agens pengendalian hayati Phytophthora capsiciLeonian pada cabai. [Tesis]. Institut Pertanian Bogor. Bogor.

Rosadiah, F.N., S. Ilyas, D. Manohara. 2015. Perlakuan benih cabai (Capsicum annuum L.) dengan rizobakteri secara tunggal ataupun kombinasi dapat mengendalikan Phytophthora capsici danmeningkatkan pertumbuhan tanaman. J. Hort. Indonesia 6(1):1-10.

Sutariati, G.A.K., Widodo, Sudarsono, S.Ilyas. 2006. Pengaruh perlakuan rizobakteri pemacu pertumbuhan tanaman terhadap viabilitas benih serta pertumbuhan bibit tanaman cabai. Bul. Agron.34(1):46-54.

Taufik, M. 2010. Pertumbuhan dan produksi tanaman cabai yang diaplikasi plant growth promoting rhizobakteria. Jurnal Agrivigor. 10(1):99-107. 
Zakia, A., S. Ilyas, C. Budiman, Syamsuddin, D. Manohara. 2017. Peningkatan pertumbuhan tanaman cabai dan pengendalian busuk phytophthora melalui biopriming benih dengan rizobakteri asal pertanaman cabai
Jawa Timur. J. Hort. Indonesia 8(3):171182. Desember 2017. 